\title{
A magyar méreggyilok (Vincetoxicum pannonicum (Borhidi) Holub 1967) ízeltlábú fogyasztói
}

\author{
FENYŐSI ZSUZSANNA \\ H-7633 Pécs, Hajnóczy út 9., Hungary \\ e-mail: fenyosizsuzsa@gmail.com
}

FENYösi, Zs.: Arthropod consumers on Vincetoxicum pannonicum (Borhidi) Holub 1967.

Abstract: Vincetoxicum pannonicum is one of the most interesting plant species in the Villány Hills, which was described by Attila Borhidi in 1967. This species is a host plant for Eumolpus asclepiadeus and Lygaeus equestris. These insect spesies were found to feed on this rare and vulnerable plant, which can affect its preservation.

Keywords: Villány Hills, Vincetoxicum pannonicum as a food plant, Eumolpus asclepiadeus, Lygaeus equestris

\section{Bevezetés}

A meténgfélék (Apocynaceae) családjába, azon belül a selyemkórófélék (Asclepiadoideae) alcsaládjába tartozó méreggyilok (Vincetoxicum syn. Cynanchum) nemzetség nevét mérgező hatásáról kapta. A hazánkban elöforduló közönséges (Vincetoxicum hirundinaria Medik.) és magyar méreggyilok (Vincetoxicum pannonicum (Borhidi) Holub) igen kevés faj számára szolgál tápnövényként, hiszen másodlagos anyagcseretermékeik (vincetoxin és aszklepiadin) erösen mérgező glikozidok (STAERK et al. 2000, MuOLA et al. 2010).

A közönséges méreggyilok fogyasztói között tartják számon a lovagbodobácsot (Lygaeus equestris L.) és a tündöklő méreggyiloklevelészt (Eumolpus asclepiadeus Pallas), mely fajok kártétele az említett taxonon természetvédelmi kockázattal nem jár (VIG 2000, GÜNTHER 1970). Hazánk fokozottan védett növényének, a magyar méreggyiloknak fogyasztóiról eddig nem állt rendelkezésre adat. Endemikus növényünk mintegy 700 egyedet számláló világállománya a Budai- és a Villányi-hegység területére korlátozódik, ahol együtt is előfordulhat a közönséges méreggyilokkal (HARASZTHY 2014).

\section{Anyag és módszer}

2018. május 19-én a Villányi-hegységben, a Szársomlyó Természetvédelmi Területen található magyar méreggyilok állomány felmérése során figyeltem meg a tündöklő méreggyiloklevelész (Eumolpus asclepiadeus Pallas) egyedeit a növény leveleinek rágása közben. Az előfordulási adat GPS koordinátája: 4551'23.1”N 18²5’37.2”E (1. ábra) A növényállomány vizsgálatának céljából három poligon került kijelölésre a 
hegy gerincének keleti lejtőjén, melyek területe lefedi a magyar méreggyilok szársomlyói előfordulásának helyeit. A $383 \mathrm{~m}^{2}, 389 \mathrm{~m}^{2}$ és $326 \mathrm{~m}^{2}$ nagyságú növényzeti foltokat két hetes gyakorisággal vizsgáltam.

A terepbejárások alkalmával rendszeresen megszámoltam a fitofág szervezeteket, valamint becsültem a károsításuk mértékét.

\section{Eredmények}

A tündöklő méreggyiloklevelész (Eumolpus asclepiadeus) két példánya került begyüjtésre, majd ezt követően meghatározásra, ahogy később a lovagbodobács (Lygaeus equestris) esetében is. A bizonyító példányokat mindkét faj esetében saját gyüjteményemben helyeztem el.

A magyar méreggyilok Villányi-hegységben előforduló 237 hajtást számláló állományának közel 75\%-án voltak megfigyelhetőek a tündöklő méreggyiloklevelész rágásnyomai. A faj lokális elterjedési térképének mindhárom poligonjában (2. ábra) tapasztalható volt a kártétel. A károsítás mértéke tehát ezen a területen igen jelentős.

Elsőként május közepén figyeltem meg nyolc imágót (3. ábra), a magyar méreggyilok előfordulását jelző poligon legnyugatibb pontján élő egyedek hajtásain. Ekkor még kevés rágásnyommal találkoztam, ezek később júniusban már szinte minden hajtáson láthatóak voltak és az imágók száma is jelentősen növekedett. A legtöbb egyszerre megfigyelt egyed száma május 19-én történt terepbejárás során 16 pld. volt.

A lovagbodobács (Lygaeus equestris) sokkal elterjedtebb országszerte, meleg, délies lejtőkön, gyepeken és erdőszéleken egyaránt (GüNTHER 1970, MóczÁR 1984). Ismert és kedvelt tápnövénye a közönséges méreggyilok. Táplálkozására jellemző, hogy növényi magvakat, nedveket szívogat (LAUKKAEN 2014). A 2018 júniusi 2-i terepbejárás során figyeltem meg a lovagbodobács (Lygaeus equestris L.) 18 egyedét, amint a fokozottan védett növény karcsú, paprikára emlékeztető, éretlen terméseit szívogatják (4. ábra). Károsításának mértéke nehezen becsülhető, hiszen a szívogatások nyomai nehezen észrevehetők. Táplálkozásával befolyásolhatja a magok életképességét, így a kártételek mérséklése fontos tényező lehet a magyar méreggyilok magprodukciójának megőrzése érdekében.

Valószínűsíthető, hogy a két méreggyilok faj között kemotaxonómiai szempontból nincs jelentős különbség, hiszen a két megfigyelt fogyasztó a közönséges és a fokozottan védett magyar méreggyilokkal egyaránt táplálkozik a Szársomlyón. A magyar méreggyilok populáció kis egyedszáma miatt kártételük járhat természetvédelmi kockázattal.

\section{Köszönetnyilvánítás}

Ez úton szeretném kifejezni köszönetem tanáromnak, Dr. Nagy Józsefnek, a cikk elkészítéséhez adott segítségéért, továbbá Dudás Györgynek (DDNP Igazgatóság), a felvételezésekben nyújtott közremüködéséért. 


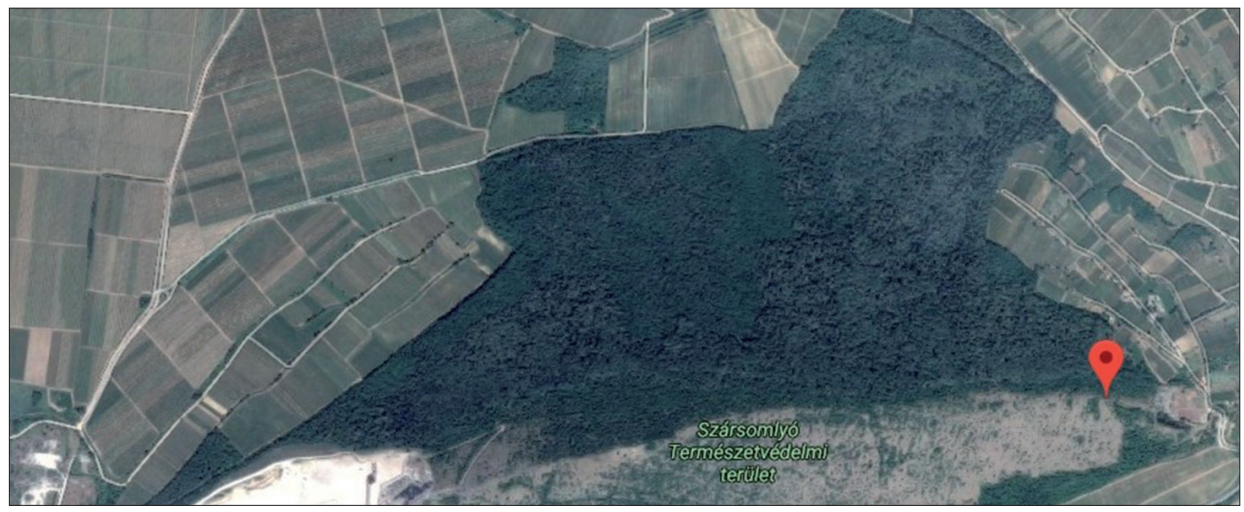

1. ábra: A magyar méreggyilok (Vincetoxicum. pannonicum) előfordulási helye a Szársomlyó keleti lejtőjén

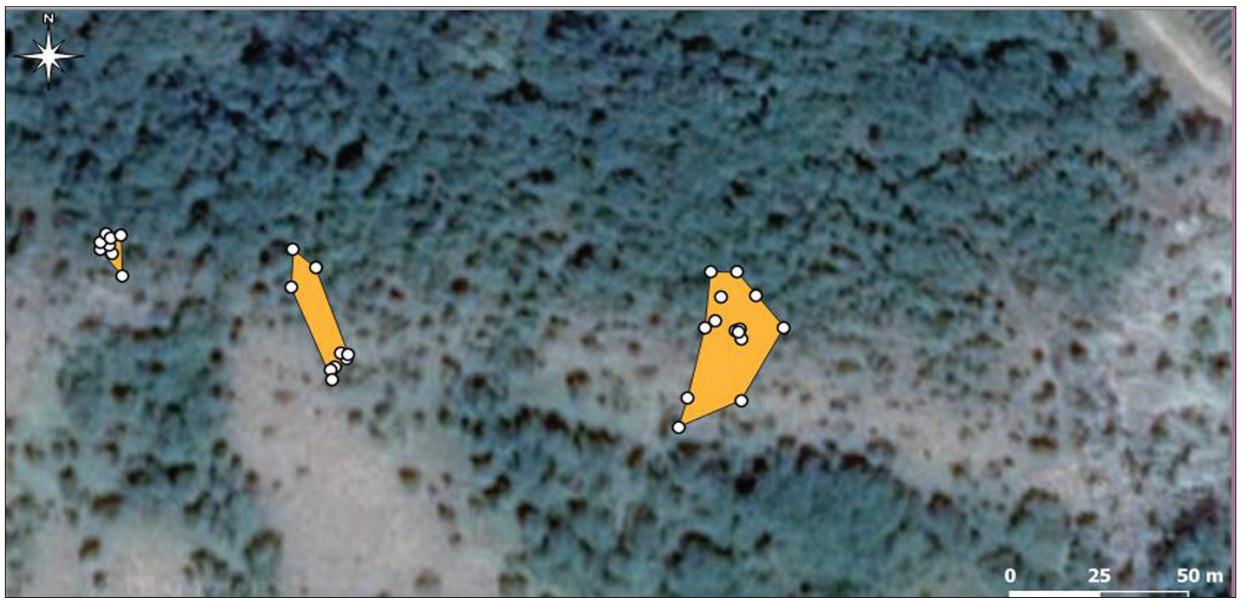

2. ábra: A magyar méreggyilok (Vincetoxicum. pannonicum) állományfoltok előfordulása a Szársomlyón

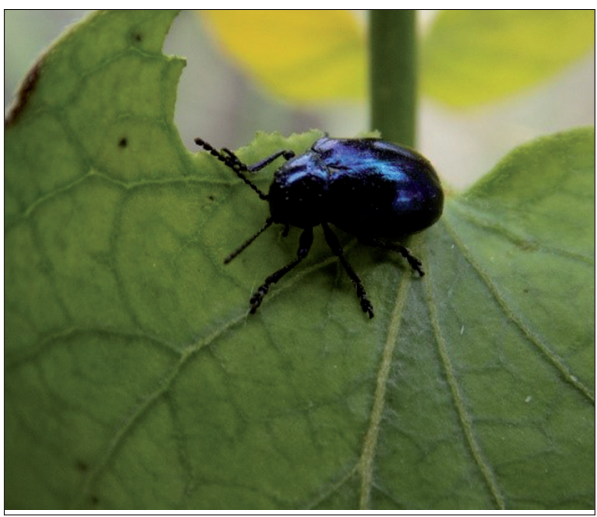

3. ábra: Vincetoxicum pannonicum levelén táplálkozó tündöklő méreggyiloklevelész (fotó: Fenyősi Zsuzsanna)

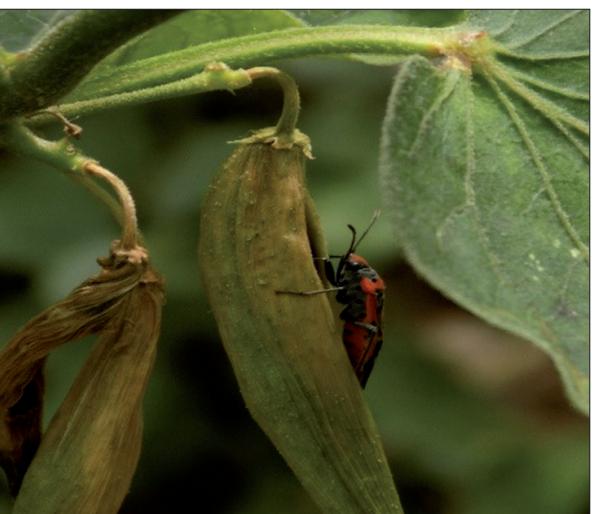

4. ábra: A Vincetoxicum pannonicum termésén táplálkozó lovagbodobács (fotó: Fenyősi Zsuzsanna) 


\section{Irodalom}

Haraszthy L. (szerk.) 2014: Natura 2000 fajok és élőhelyek Magyarországon. Pro Vértes Természetvédelmi Közalapítvány. Csákvár, pp. 82-84.

GÜNTHER K. 1970: Uránia Állatvilág - Rovarok. Gondolat Kiadó, pp. 138-139. Budapest

LaukKaen, L. 2014: Population genetics, food-plant specialization, and local adaptation of insect herbivores living in a fragmented landscape.-University of Turku, Turku 2014. pp.17-18

MóczÁr L. (szerk.) 1984: Állathatározó I.- Tankönyvkiadó, Budapest: pp. 562-563.

Muola, A., Mutikainen, P., Laukkanen, L., Lilley, M. \& Leimu, R. 2010: Genetic variation in herbivore resistance and tolerance: the role of plant life-history stage and type of damage. Journal of Evolutionary Biology 23(10): 2185-2196.

Stærk, D., Christensen, J., Lemmich, E., Duus, J. Ø., Olsen, C. E. \& Jaroszewski, J. W. 2000: Cytotoxic activity of some phenanthroindolizidine N-oxide alkaloids from Cynanchum vincetoxicum. - Journal of Natural Products 63: 1584-1586.

VIG K. 2000: A Villányi-hegység levélbogár faunája (Coleptera, Chrysomelidae sensu lato). - Dunántúli Dolgozatok Természettudományi Sororozat (Pécs) 10: 229-248. 